\title{
PENGARUH PENGGANTIAN POLLARD DENGAN DEDAK PADI YANG DISUPLEMENTASI MULTIVITAMIN-MINERAL DALAM KONSENTRAT TERHADAP PENAMPILAN SAPI BALI JANTAN
}

\author{
MELATI N. P. Y., I G. L. O. CAKRA, DAN I. B. G. PARTAMA \\ Program Studi Magister Ilmu Peternakan, \\ Fakultas Peternakan, Universitas Udayana, Denpasar \\ Jl. P.B. Sudirman. Denpasar, Bali \\ email : yundarimela@gmail.com
}

\begin{abstract}
ABSTRAK
Tujuan penelitian ini untuk mengetahui pengaruh penggantian pollard dengan dedak padi yang disuplementasi multivitamin-mineral $0,1 \%$ dalam konsentrat terhadap penampilan sapi bali jantan. Penelitian ini dilaksanakan selama tiga bulan pada bulan Oktober sampai Desember 2017 di Kelompok Tani Ternak Amerta Sari Desa Kesiut, Kec. Kerambitan Kab. Tabanan dan analisis sampel di Laboratorium Nutrisi dan Makanan Ternak Fakultas Peternakan Universitas Udayana. Rancangan yang digunakan dalam penelitian ini rancangan acak kelompok (RAK) dengan tiga perlakuan dan enam kelompok sebagai ulangan pada setiap perlakuan. Perlakuan tersebut yaitu rumput lapangan ad libitum ditambah konsentrat A 1\% BK dari bobot badan ternak (RA); rumput lapangan ad libitum ditambah konsentrat B 1\% BK dari bobot badan ternak (RB); dan rumput lapangan ad libitum ditambah konsentrat C 1\% BK dari bobot badan ternak (RC). Hasil penelitian menunjukkan bahwa sapi bali yang diberikan pakan rumput lapangan ad libitum dengan ditambah konsentrat $\mathrm{C}(\mathrm{RC})$ memiliki penampilan antar perlakuan berbeda tidak nyata $(\mathrm{P}>0,05)$ dengan pertambahan berat badan $0,69-0,72 \mathrm{~kg} / \mathrm{hari}$ serta konversi pakan terendah 7,32. Simpulan dari penelitian ini bahwa penggantian pollard dengan dedak padi tanpa dan dengan suplementasi multivitamin mineral dalam konsentrat memberikan respon yang sama terhadap penampilan sapi bali.
\end{abstract}

Kata kunci: sapi bali, pollard, dedak padi, multivitamin-mineral, penampilan

\section{SUPLEMENTATION OF MULTIVITAMIN-MINERALS IN RICE BRAN TO REPLACE POLLARD IN CONCENTRATE ON PERFORMANCE OF BALI CATTLE}

\begin{abstract}
The purpose of this study is to investigate about substitution pollard with rice bran supplemented multivitaminmineral in concentrate on performance of bali cattle. The study was conducted for three months from October to December 2017 at the Amerta Sari Kesiut Village, Tabanan regency and sample analysis at the Nutrition and Feeding Laboratory Faculty of Animal Husbandry Udayana University. The design used in this study was randomized block design (RBD) with three treatments instead of six groups as replicates in each treatment. The treatment is ad libitum grass plus concentrate A $1 \%$ of body weight (RA); ad libitum grass plus concentrate B $1 \%$ of body weight (RB); and ad libitum grass plus concentrate $\mathrm{C} 1 \%$ of body weight (RC). The result of the research showed that bali cattle were given of ad libitum grass feed with added concentrate $\mathrm{C}$ (RC) the treatment was not significantly different $(\mathrm{P}>0.05)$ with $0.69-0.72 \mathrm{~kg} /$ day of weight gain and the lowest feed conversion of 7.32 . Conclusion from this research that the replacement of pollard with rice bran which supplementation of multivitamin mineral $0,1 \%$ in concentrate is feasible, indicated by the performance of bali cattle tend to be better with the highest body weight gain of $0.72 \mathrm{~kg} /$ day, the lowest feed conversion of 7.32. From this research, it can be concluded that the replacement of pollard with rice bran without and with multivitamin mineral supplementation in the concentrate gave the same response to the performance of bali cattle.
\end{abstract}

Keywords: pollard, ric e bran, multivitamin-mineral, performance 


\section{PENDAHULUAN}

Sapi bali (Bos sondaicus) adalah hewan plasma nutfah dari Provinsi Bali yang merupakan bibit ternak terbaik di daerah tropis (Diwyanto, 2006). Ada dua hal umum yang dapat mempengaruhi penampilan ternak yaitu genetik dan lingkungan. Salah satu faktor lingkungan yang penting untuk diperhatikan adalah ketersediaan bahan pakan dalam hal kualitas dan kuantitas. Pemberian pakan berkualitas akan meningkatkan produktivitas ternak. Pakan adalah kategori pakan yang dibutuhkan oleh ternak ruminansia dalam jumlah besar. Rumput lapang adalah makanan utama ternak ruminansia, yang sering disediakan oleh petani karena mudah ditemukan di sekitar kandang dan sawah. Selain itu, padang rumput memiliki kemampuan pertumbuhan yang tinggi, terutama di daerah tropis, meski sering dipotong. Di sisi lain rumput lapangan memiliki kandungan nutrisi yang sangat rendah dari yaiu PK 6-8\%, 60\% TDN dan SK 28.06\% (Mathius et al., 2002).

Kandungan karbohidrat mudah larut yang rendah disertai serat kasar yang tinggi, menyebabkan kecernaan hijauan rumputlapanganmenjadirendahdanmembatasi konsumsi pakan, sehingga ternak sering mengalami kekurangan nutrisi. Imbangan pakan konsentrat sangat dibutuhkan dalam mengatasi hal tersebut. Salah satu pakan tambahan penyusun konsentrat yang umumnya diberikan oleh peternak adalah dedak gandum (pollard). Pollard merupakan limbah industri pertanian hasil sampingan dari pengolahan gandum. Namun, pada kondisi tertentu ketersediaan pollard sulit didapatkan oleh peternak disamping harga yang relatif mahal. Sehingga pemanfaatan bahan pakan sebagai penyusun konsentrat perlu dipilih yang berasal dari limbah pertanian berbahan baku lokal yaitu dedak padi. Kandungan nutrien dedak padi hampir mendekati nutrien pollard yaitu PK 13,5\%, ME $2.460 \mathrm{kcal}$, BK 86\%, SK 12\% dan TDN 73\% (Hartadi et al., 1990).

Penyusunan bahan pakan konsentratyang terdiri atas bahan hasil ikutan agroindustri seperti pollard, dedak padi, bungkil kedelai maupun hasil ikutan industri lain disatu sisi dapat meningkatkan ketersediaan protein dan energi siap pakai, namun belum mampu mengatasi rendahnya kandungan mineral dan vitamin mengingat hasil ikutan agroindustri yang dihasilkan didaerah tropis umumnya memiliki kandungan vitamin dan mineral yang rendah (Kaunang, 2004). Selain itu, bahan pakan dedak padi telah mengalami pemanasan saat proses penggilingan padi yang menyebabkan hilangnya kandungan beberapa vitamin didalamnya (Kuswandi, 2002). Selain kandungan vitamin yang hilang, mineral pada dedak padi juga masih terikat oleh asam pitat, sehingga ketersediaanya pada pakan sedikit dan perlu dilakukan suplementasi multivitamin-mineral untuk mengatasi kekurangan tersebut.

Suplementasi vitamin dan mineral pada bahan pakan ternak berperan dalam proses metabolisme yang dibutuhkan oleh mikroba rumen terutama dalam aktivitasnya mencerna selulosa dan pertumbuhan hewan inang (Parakkasi, 1999). Berdasarkan uraian tersebut peneliti tertarik untuk melakukan suplementasi multivitamin dan mineral pada konsentrat sapi bali dengan pakan dasar rumput lapangan. Penelitian ini bertujuan untuk mengetahui dan mengevaluasi mengenai pengaruh penggantian pollard dengan dedak padi yang disuplementasi multivitamin mineral dalam konsentrat terhadap penampilan sapi bali.

\section{MATERI DAN METODE}

\section{Materi}

Materi yang digunakan dalam penelitian ini diantaranya ternak sapi bali jantan sebanyak 18 ekor dengan rata-rata bobot badan awal sapi berkisar antara $127 \pm 19,46 \mathrm{~kg}$, yang masing-masing dipelihara sesuai dengan perlakuan selama tiga bulan. Kandang yang dipergunakan dalam penelitian ini adalah kandang individu. Atap kandang menggunakan asbes dengan ukuran tiap petak kandang adalah; panjang 200 $\mathrm{cm}$, lebar $150 \mathrm{~cm}$, dan tinggi $200 \mathrm{~cm}$ bagian depan dan $180 \mathrm{~cm}$ bagian belakang terbuat dari beton dan bambu sebagai penyekat. Pakan yang digunakan dalam penelitian ini terdiri atas dua jenis pakan yaitu hijauan sebagai pakan dasar dan konsentrat. Dimana sumber hijaun yang digunakan dalam penelitian ini yaitu rumput lapangan yang diberikan secara adlibitum dan konsentrat 1\% BK dari bobot badan ternak. Rumput lapangan yang digunakan adalah rumput yang tumbuh di segala macam tanah dan tumbuh liar di tepi jalan ataupun di tepi sawah dengan beragam spesies.

\section{Lokasi dan Waktu Penelitian}

Penelitian ini dilaksanakan pada Kelompok Tani Ternak (KTT) Amerta Sari Desa Kesiut Kecamatan Kerambitan, Kabupaten Tabanan selama 12 minggu. Dua minggu pertama untuk persiapan alat dan bahan penelitian, serta masa adaptasi ternak terhadap pakan perlakuan yang diberikan. Penelitian pada ternak dilakukan 10 minggu berikutnya. Analisis sampel dilaksanakan di Laboratorium Nutrisi dan Makanan Ternak Fakultas Peternakan Universitas Udayana Denpasar.

\section{Alat dan Bahan}

Alat-alat yang digunakan dalam penelitian adalah timbangan digital, timbangan duduk, terpal, kantong plastik, ember, pisaudan alat tulisuntuk keperluan 
pengumpulan data kegiatan penelitian. Bahanbahan yang digunakan adalah: susunan bahan pakan konsentrat $\mathrm{A}$, konsentrat $\mathrm{B}$ dan konsentrat $\mathrm{C}$, rumput lapangan dan air minum.

\section{Susunan Bahan Pakan Konsentrat}

Konsentrat yang dipergunakan dalam penelitian ini berasal dari bahan baku limbah agroindustri. Konsentrat diberikan dalam bentuk mash (tepung) yang disusun berdasarkan perhitungan komposisi zat-zat makanan menurut rekomendasi Kearl (1982). Bahan-bahan penyusun konsentrat A, B dan C terdiri atas dedak padi, tepung jagung, bungkil kedelai, pollard, gritz. Multivitamin mineral $0,1 \%$ ditambahkan hanya pada konsentrat C. Pakan diberikan dua kali yaitu pada pagi hari dan sore hari.

Tabel 1. Komposisi bahan penyusun konsentrat penelitian

\begin{tabular}{lccc}
\hline \multirow{2}{*}{ Komposisi Bahan (\%) } & \multicolumn{3}{c}{ Konsentrat } \\
\cline { 2 - 4 } & $\mathrm{A}$ & $\mathrm{B}$ & $\mathrm{C}$ \\
\hline Dedak Padi & 0,00 & 23,00 & 22,9 \\
Tepung Jagung & 40,0 & 40,00 & 40,0 \\
Bungkil Kedele & 34,0 & 34,00 & 34,0 \\
Pollard & 23,0 & 0,00 & 0,00 \\
Grit & 3,00 & 3,00 & 3,00 \\
Pignox & 0,00 & 0,00 & 0,10 \\
Total & 100 & 100 & 100 \\
\hline
\end{tabular}

Tabel 2. Kandungan nutrien konsentrat penelitian

\begin{tabular}{lcccc}
\hline \multirow{2}{*}{ Kandungan Nutrien } & \multicolumn{3}{c}{ Konsentrat $^{1 \text { ) }}$} & Rumput $^{1)}$ \\
\cline { 2 - 5 } & $\mathrm{A}$ & $\mathrm{B}$ & $\mathrm{C}$ \\
\hline Bahan kering (\%) & 88,86 & 89,38 & 89,39 & 20,79 \\
Bahan organik (\%) & 78,25 & 77,27 & 77,25 & 72,69 \\
Protein kasar (\%) & 22,40 & 21,05 & 21,05 & 12,50 \\
Lemak kasar (\%) & 2,40 & 2,03 & 2,02 & 3,89 \\
Serat kasar (\%) & 10,46 & 12,67 & 12,65 & 23,71 \\
TDN (\%) & 55,14 & 52,06 & 52,00 & 49,50 \\
\hline
\end{tabular}

Keterangan:

1) Hasil Analisis Laboratorium Nutrisi Ternak Fakultas Peternakan Universitas Udayana

Tabel 3. Kebutuhan nutrisi sapi

\begin{tabular}{lccccccc}
\hline $\begin{array}{l}\text { Berat badan } \\
\text { sapi (kg) }\end{array}$ & $\begin{array}{c}\text { PBBH } \\
(\mathrm{kg})\end{array}$ & $\begin{array}{c}\mathrm{BK} \\
(\mathrm{Kg})\end{array}$ & $\begin{array}{c}\mathrm{ME} \\
(\mathrm{Mcal})\end{array}$ & $\begin{array}{c}\mathrm{TDN} \\
(\mathrm{g})\end{array}$ & $\begin{array}{c}\mathrm{PK} \\
(\mathrm{g})\end{array}$ & $\begin{array}{c}\mathrm{Ca} \\
(\mathrm{g})\end{array}$ & $\begin{array}{c}\mathrm{P} \\
(\mathrm{g})\end{array}$ \\
\hline $\begin{array}{l}\text { Sapi jantan } \\
(150 \mathrm{~kg})\end{array}$ & 0 & 3,00 & 5,10 & 1,40 & 231 & 6 & 6 \\
$\begin{array}{l}\text { Sapi jantan } \\
(150 \mathrm{~kg})\end{array}$ & 0,25 & 3,80 & 6,56 & 1,80 & 400 & 12 & 9 \\
$\begin{array}{l}\text { Sapi jantan } \\
(150 \mathrm{~kg})\end{array}$ & 0,50 & 4,20 & 8,02 & 2,20 & 474 & 16 & 10 \\
$\begin{array}{l}\text { Sapi jantan } \\
(150 \mathrm{~kg})\end{array}$ & 0,75 & 4,40 & 9,55 & 2,60 & 589 & 21 & 13 \\
$\begin{array}{l}\text { Sapi jantan } \\
(150 \mathrm{~kg})\end{array}$ & 1,00 & 4,50 & 10,93 & 3,00 & 607 & 27 & 16 \\
\hline
\end{tabular}

Keterangan: Kearl (1982)

\section{Rancangan Percobaan}

Rancangan percobaan penelitian yang digunakan adalah rancangan acak kelompok (RAK) yang terdiri atas tiga perlakuan dan enam kelompok (blok) sebagai ulangan pada setiap perlakuan, sehingga secara keseluruhan terdapat 18 unit percobaan. Pengelompokan ternak sapi berdasarkan bobot badan. Tiap unit percobaan menggunakan satu (1) ekor sapi bali jantan. Perlakuan yang digunakan dalam penelitian ini adalah rumput lapangan ad libitum ditambah konsentrat A 1\% BK dari bobot badan ternak (RA), rumput lapangan ad libitum ditambah konsentrat B 1\% BK dari bobot badan ternak (RB), dan rumput lapangan ad libitum ditambah konsentrat C $1 \%$ BK dari bobot badan ternak (RC).

\section{Variabel Penelitian}

Variabel yang diamati dalam penelitian ini adalah penampilan sapi bali yang meliputi: berat badan awal, berat badan akhir, pertambahan berat badan, konsumsi pakan dan feed convertion ratio (FCR).

\section{Analisis Data}

Data yang diperoleh dari hasil penelitian ini dianalisis dengan menggunakan analisis sidik ragam, apabila terdapat perbedaan yang nyata antar perlakuan $(\mathrm{P}<0,05)$ maka dilanjutkan dengan Uji Wilayah Berganda Duncan (Steel and Torrie, 1993). Pengolahan data menggunakan program SPSS 24.

\section{HASIL DAN PEMBAHASAN}

Pengaruh pengantian pollard dengan dedak padiyang disuplementasi multivitamin mineral dalam konsentrat terhadap rataan berat badan awal, berat badan akhir, pertambahan bobot badan, feed convertion ratio (FCR) dan konsumsi pakan disajikan pada Tabel 4.

Tabel 4. Penampilan sapi bali yang diberikan pakan pollard yang diganti dengan dedak padi tersuplementasi multivitaminmineral dalam konsentrat

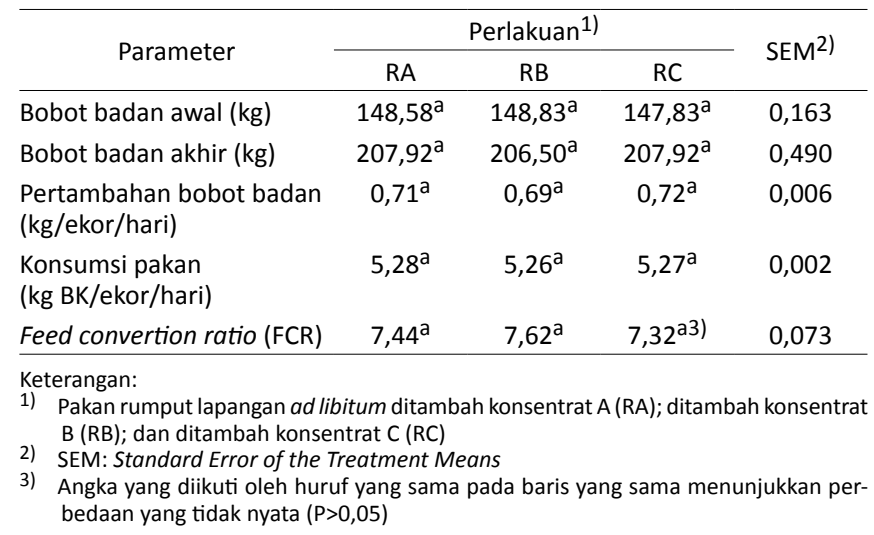

Hasil penelitian menunjukkan pada perlakuan RA, RB dan RC memiliki rataan bobot badan akhir yang antar perlakuan berbeda tidak nyata 
( $\mathrm{P}>0,05)$ berturut-turut adalah $207,92 \mathrm{~kg} ; 206,50$ $\mathrm{kg}$ dan 207,92 kg, perlakuan $\mathrm{RB}$ lebih rendah $0,68 \%$ dibandingkan perlakuan RA; RC, namun secara statistik menunjukkan hasil yang berbeda tidak nyata $(\mathrm{P}>0,05)$ antar perlakuan. Hal ini disebabkan jumlah pakan dan kandungan nutrien pakan yang dikonsumsi antar perlakuan yang diberikan tidak berbeda nyata (P>0,05) (Tabel 2). Bobot badan akhir ditentukan oleh jumlah konsumsi dan kandungan nutrien pakan yang diberikan serta jumlah nutrien yang mampu diserap oleh tubuh ternak. Hal ini seiring pendapat Tillman et al. (1991) bahwa makanan merupakan faktor yang mendominasi kecepatan pertambahan bobot badan akibat kandungan nutrien pakan yang mudah diserap dalam menunjang pembentukan jaringan tubuh ternak. Hal ini didukung pula oleh Nurwahidah (2016) bahwa nilai nutrisi pakan yang mencukupi kebutuhan hidup ternak akan memberikan pengaruh positif terhadap pertumbuhannya yang ditunjukkan dengan meningkatnya berat badan ternak. Pengaruh penggantian pollard dengan dedak padi yang disuplementasi multivitamin mineral dalam konsentrat terhadap bobot badan tersaji pada Gambar 1.

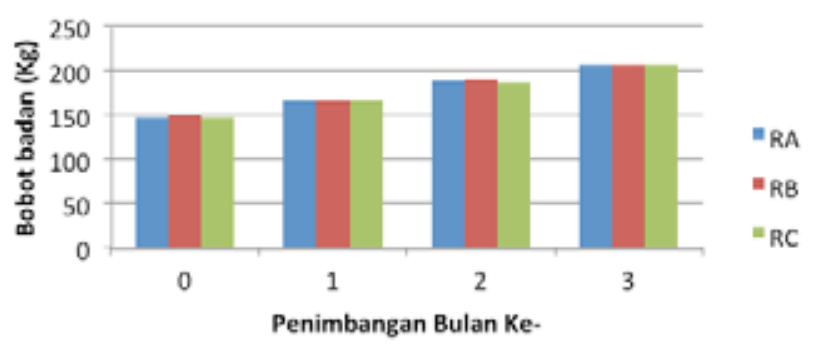

Gambar 1. Penampilan sapi bali

Rataan pertambahan bobot badan harian ternak pada perlakuan RA, RB dan RC berturut-turut adalah $0,71 \mathrm{~kg} /$ ekor, $0,69 \mathrm{~kg} /$ ekor dan 0,72 kg/ekor (Tabel 5.1). Sapi bali yang diberikan perlakuan RC lebih tinggi 1,26\% dan RB lebih rendah 2,81\% dibandingkan perlakuan RA, namun secara statistik menunjukkan hasil yang berbeda tidak nyata $(\mathrm{P}>0,05)$. Pertambahan bobot badan merupakan selisih antara bobot badan awal dan bobot badan akhir yang juga secara statistik memiliki hasil berbeda tidak nyata $(\mathrm{P}>0,05)$. Tingginya pertambahan bobot badan total pada sapi yang mendapat perlakuan $\mathrm{RC}$ disebabkan karena paling efisien dalam mengubah pakan yang dikonsumsi menjadi bobot badan, hal ini terlihat dari angka FCR pada perlakuan RC yaitu 7,32.

Wahyu (2004) melaporkan bahwa pertambahan berat badan sangat ditentukan oleh tinggi rendahnya konsumsi nutrien pakan ternak. Peningkatan berat badan akhir dan pertambahan berat badan sapi baliyang diberikan perlakuan RC (suplementasi multivitamin mineral) juga disebabkan oleh adanya suplementasi multivitamin mineral yang mampu meningkatkan aktivitas enzim pencernaan seperti karboksi peptidase oleh mineral $\mathrm{Zn}$ yang membantu proses metabolisme karbohidrat dan protein sehingga penyerapan hasil metabolisme pada saluran pencernaan dapat optimal. Selain itu adanya ketersediaan vitamin A, D, dan E dalam multivitamin mineral yang dapat meningkatkan pertambahan bobot badan sapi (Partama et al. 2014). Hal tersebut sesuai dengan penelitian Sio (2010) bahwa adanya suplementasi multi vitamin mineral $0,10 \%$ dalam ransum sapi bali penggemukan berbasis rumput gajah menghasilkan pertambahan bobot badan optimal mencapai $0,66 \mathrm{~kg} / \mathrm{ekor} /$ hari.

Konsumsipakan pada setiapperlakuan menunjukkan hasil yang berbeda tidak nyata $(\mathrm{P}>0,05)$. Hasil penelitian menunjukkan bahwa konsumsi pakan pada perlakuan $\mathrm{RB}$ dan RC masing-masing lebih rendah o,38\% dan o,19\% dibandingkan dengan perlakuan RA. Hal ini mengindikasikan layak dilakukan penggantian pollard dengan dedak padi dalam konsentrat karena memiliki tingkat palatabilitas pakan yang relatif sama sehingga konsumsi pakan hampir sama antar perlakuan. Namun, secara kuantitaif adanya suplementasi multivitamin mineral o,1\% pada perlakuan RC mampu meningkatkan konsumsi secara kuantitatif, hal ini dapat disebabkan oleh adanya peningkatan keseimbangan makro dan mikro nutrien dalam bahan pakan akan meningkatkan kemampuan mikroba rumen untuk beraktivitas yang ditunjukkan dengan terjadinya peningkatan konsentrasi VFA dan $\mathrm{N}-\mathrm{NH}_{3}$ masing-masing sebesar 103,73 mM dan 9,03 mM (Melati et al., 2018) Lebih lanjut dijelaskan, peningkatan aktivitas mikroba rumen akan mampu meningkatkan laju alir pakan dalam rumen dan merangsang ternak untuk mengkonsumsi pakan kembali sehingga jumlah konsumsi pakan meningkat pada perlakuan RC dibandingkan RB (tanpa suplementasi multivitamin mineral). Hal ini sejalan penelitian Peterson (2006) bahwa adanya suplementasi multivitamin mineral dalam ransum mampu meningkatkan laju alir pakan sehingga konsumsi mampu meningkat hingga $15 \%$.

Nilai feed convertion ratio (FCR) dari penelitian ini memperoleh hasil antar perlakuan berbeda tidak nyata $(\mathrm{P}>0,05)$ berturut-turut yaitu 7,44, 7,62 dan 7,32 pada perlakuan RA, RB dan RC yang secara statistik menunjukkan hasil berbeda tidak nyata $(\mathrm{P}>0,05)$ antar perlakuan. Feed convertion ratio (FCR) merupakan salah satu tolak ukur dalam menilai tingkat efisiensi penggunaan ransum. Semakin besar nilai konversi pakan menunjukkan ternak tidak efisien dalam menggunakan ransum untuk peningkatan bobot badannya. Secara kuantitatif perlakuan RC memiliki nilai feed convertion ratio (FCR) paling rendah dibandingkan perlakuan 
lainnya. Ini menunjukkan efisiensi penggunaan ransum perlakuan RC paling tinggi. Nilai FCR pada perlakuan RC yang rendah dapat disebabkan oleh proses metabolisme dan penyerapan pakan dalam rumen yang berjalan optimal karena adanya kecukupan dan keseimbangan nutrien pakan yang dibutuhkan ternak. Mineral $\mathrm{Zn}$ dalam multivitamin mineral mampu meningkatkan aktivitas mikroba rumen melalui enzim pensintesis protein seperti DNA dan RNA polimerase, sehingga nutrien yang masuk kedalam sel lebih banyak dimanfaatkan untuk mensintesis jaringan tubuh sehingga dapat meningkatkan pertambahan bobot badan sapi bali (Tillman et al., (1984). Hasil penelitian ini sejalan dengan penelitian Hermawan (2006) menunjukkan suplementasi ammonium sulfat (0,05\%) dan pignox $(0,03 \%)$ mampu meningkatkan FCR yang dihasilkan oleh sapi bali jantan penggemukan sebesar 6 ,9. Nilai feed convertion ratio (FCR) memiliki arti yang sangat penting dalam manajemen usaha penggemukan sapi potong yang dijadikan dasar dalam mengambil keputusan dalam pemeliharaan (Parakkasi, 1999).

\section{SIMPULAN}

Penggantian pollard dengan dedak padi yang disuplementasi multivitamin mineral $0,1 \%$ belum mampu meningkatkan penampilan sapi bali.

\section{UCAPAN TERIMAKASIH}

Pada kesempatan ini kami mengucapkan banyak terimakasih kepada Rektor Universitas Udayana, Ketua Progran Studi Magister Ilmu Peternakan Universitas Udayana, Dekan Fakultas Peternakan Universitas Udayanadan kedua pembimbing atas pelayanan administrasi, fasilitas pendidikan yang diberikan serta bimbingan kepada penulisselama menjalani perkulihaan dan penyusunan tesis.

\section{DAFTAR PUSTAKA}

Dwiyanto, K dan E. Handiwirawan. 2006. Strategi Pengembangan Ternak Kerbau: Aspek penjaringan dan distribusi. Pros. Lokakarya Nasional Usaha Ternak Kerbau Mendukung Program Kecukupan Daging Sapi Puslitbang Peternakan, Bogor.

Hartadi, H. S, Reksohadiprodjo. dan A. D, Tillman. 1990. Tabel Komposisi Pakan untuk Indonesia. Gadjah Mada University. Yogyakarta.

Hermawan, D. 2006. Pengaruh Suplementasi Mineral dalam Ransum yang Mengandung Jerami Padi Amoniasi Urea Terhadap Konsentrasi VFA Parsial, gas Metan dan Konversi Ransum pada sapi Bali penggemukan. Jurnal Peternakan Tropika Vol. 6 (1) 2006: 18 - 26
Kaunang, C. L. 2004. Respon Ruminan Terhadap Pemberian Hijauan Pakan yang Dipupuk Air Belerang. Disertasi. Program Pasca Sarjana IPB, Bogor. URL: http://www. damandiri.or.id/files/chairlesipb.pdf.

Kearl, L. C. 1982. Nutrient Requirement of Ruminants in Developing Countries. International Feedstuff Institute. Utah Agric. Exp. Station. Unite State University. Logan Unite.

Kuswandi, C., Talib, A. R., Siregar dan T. Sugiarti. 2002. Performans Sapi Dara Calon Induk Terseleksi Pengaruh Kandungan Dedak Padi dalam Konsentrat. Journal Seminar Nasional Teknologi Peternakan dan Veteriner.

Mathius, I. W., D. Yulistiani dan W. Puastuti. 2002. Pengaruh Substitusi Protein Kasar dalam Bentuk Bungkil Kedelai Terproteksi Terhadap Penampilan Domba Bunting dan Laktasi. JITV 7 (1): 22 - 29

Melati N. P. Y., I. G. L. O. Cakra, dan I. B. G. Partama. 2018. Pengaruh Penggantian Pollard dengan Dedak Padi yang Disuplementasi Multivitamin-Mineral dalam Konsentrat terhadap Penampilan Sapi Bali. Tesis. Fakultas Peternakan. Universitas Udayana

Nurwahidah. 2006. Pengetahuan Bahan Pakan. Nutrisi Sejahtera Press Bogor

Partama, I. B. G., I G. L. Oka Cakra, dan A. AA. S. Trisnadewi. 2014. Optimalizing Microbial Protein Synthesis n The Rumen Throuh Supplementation With Vitamin and Minerals in Ration Based on King Grass to Increase Bali Cattle Productivity. Journal of Biological and Chemical Research Vol 31 (2) 2014 Pages 822 -840.

Parakkasi, A. 1999. Ilmu Nutrisi dan Makanan Ternak Ruminan. Penerbit Universitas Indonesia. Jakarta. Peterson, A. B. 2006. Estimation of Rumen Microbial Protein Production and Ruminal Protein Degradation. Desertasi. Department of Animal and Avian Science. University of Maryland, College Park. Available from: URL: http//: drum. Umd. Edu/dspace/ handle/1903/ $386511 \mathrm{k} /$.

Sio, S. 2010. Penampilan Sapi Bali yang Diberi Ransum Berbasis Rumput Gajah (Pennisetum purpureum) dengan Suplementasi Multi Vitamin dan Mineral. Jurnal Majalah Ilmiah Peternakan. Fakultas Peternakan. Universitas Udayana.

Steel R. G. D danJ. H Torrie. 1993. Prinsi and Prosedur Statistika, Suatu Pendekatan Biometrik. PT. Gramedia, Jakarta.

Tillman, A.D., H. Hartadi, S. Reksohadiprodjo, S. Prawirokusumo, dan S. Lebdosoekojo. 1984. Ilmu Makanan Ternak Dasar. Gadjah Mada University Press. Yogyakarta.

Wahyu, J. 2004. Ilmu Nutrisi Ternak Unggas. Cetakan ke Lima. Gadjah Mada University Press. Yogyakarta. 